\title{
ECONOMY
}

\section{FISCAL POLICY AIMED AT ENSURING THE EQUIVALENCY OF THE BUDGET IN THE MEDIUM TERM IN UZBEKISTAN}

\author{
Islamkulov Kh. Alimnazar, PhD., Associate professor, \\ Academy of Public Administration under the President of the Republic of Uzbekistan \\ Tashkent, Uzbekistan
}

DOI: https://doi.org/10.31435/rsglobal_sr/30112019/6813

\section{ARTICLE INFO}

Received 12 September 2019 Accepted 08 November 2019 Published 30 November 2019

\section{KEYWORDS}

fiscal policy, budget equivalency, medium-term budget, independence budgetary institutions.

\begin{abstract}
This article covers such issues as reforms carried out in Uzbekistan on the reform of public finances, the use of advanced foreign experience in the transition to medium-term budget planning, the role of independent budgetary institutions in the correct and purposeful use of budgetary funds.
\end{abstract}

Citation: Islamkulov Kh. Alimnazar. (2019) Fiscal Policy Aimed at Ensuring the Equivalency of the Budget in the Medium Term in Uzbekistan. Science Review. 9(26). doi: 10.31435/rsglobal_sr/30112019/6813

Copyright: (C) 2019 Islamkulov Kh. Alimnazar. This is an open-access article distributed under the terms of the Creative Commons Attribution License (CC BY). The use, distribution or reproduction in other forums is permitted, provided the original author(s) or licensor are credited and that the original publication in this journal is cited, in accordance with accepted academic practice. No use, distribution or reproduction is permitted which does not comply with these terms.

Fiscal policy is an important component of Public Policy. Fiscal policy, the regulation of the economy through taxes is ensured. This policy stipulates the amount of gross domestic product created in the country to be distributed by the state, the distribution of the state functions and duties of the GDP obtained at the state's disposal. Proceeding from this, the directions of economic reforms of the state are determined.

President Of The Republic Of Uzbekistan Addressed To The Oliy Majlis said that "It is necessary to further improve the system of effective use of budgetary funds .... any program or project that funds from a budget account consists of quality and quantity indicators, should have resultoriented indicators" ". The performance of this task in turn is closely related to the fiscal strategy for the medium-term perspective as well supporting interbudgaetary inequality.

In addition, in the state program on implementation of the strategy of action on five priority directions of development of the Republic of Uzbekistan in 2017-2021 in the "year of active investment and Social Development"additional opportunities and reduction of budget deficit from the account of resources; further improvement of the system of effective use of budgetary funds; improvement of budgetary relations and reduction of the degree of dependence of local budgets on high-resident budgets; establishment of effective tax administration; development of a new amendment of the tax code, ensuring the stability of the price of consumer products and nonexceeding the forecast indicators of the level of inflation ${ }^{2}$.

\footnotetext{
${ }^{1}$ President of the Republic of Uzbekistan addresses the Oliy Majlis. https://president.uz/en/lists/view/2221

${ }^{2}$ Decree of the President of the Republic of Uzbekistan on $17^{\text {th }}$ of January 2019 "About the state program on implementation of Strategy of actions on five priority directions of development of the Republic of Uzbekistan in 2017-2021 IN "Year of active investments and social development»
} 
According to the "Road map"of the main directions of structural reforms in the Republic of Uzbekistan in 2019-2021 in cooperation with the World Bank and other international financial institutions, maintenance of macroeconomic stability, effective fiscal policy, radical reform of the taxation system and tax administration were defined as a special direction.

In some sectors of the economy, taking into account the fact that entrepreneurs are given a significant amount of privileges and preferences, the existing imbalances in the current order of calculating and paying value added tax create a full-fledged chain of Value Added Tax in the provision of equal conditions for all economic entities and increase the competitiveness of the economy and, a new approach has begun to regulate the practice of ensuring the introduction of the principles of fair competition and granting privileges on taxes and duty payments.

Over the past period (2017-2019), local budgets in Uzbekistan have been achieved to increase the source of income, to ensure their financial independence, to ensure the equivalency of the budget as a result of improvement of the distribution of taxes (shared taxes) ${ }^{1}$ between budgets of different levels.

Among the important innovations in the field of Public Finance Management, international experts include the creation of independent budgetary institutions ${ }^{2}$.

In international practice, it is understood that independent budgetary institutions are organizations that are financed from the state budget, but independent of financial and budgetary bodies, operate under the supervision of legislative or high-executive authorities, control and analyze the sphere of budgetary policy and budgetary indicators (in some cases together with the provision of recommendations). Independent budgetary institutions were established with the aim of strengthening budgetary discipline, increasing the openness and accountability of budgetary policy, improving the quality of public discussion on budgetary policy issues. National banking activities are viewed by international organizations as an important indicator of openness and transparency of Public Finance Management System.

It also performs the function of controlling the management of public finances of independent budgetary institutions. It is noted that in most countries there is a risk that their impact will be weakened and control functions will decrease if the national accounts chambers and other independent organizations are actively involved in the debate on budgetary policy issues. The creation of independent budgetary institutions allows, according to experts from the European Union, to consolidate the activities of such organizations and improve the quality of communication between state and public structures on public finance . $^{3}$

In 2016, independent budgetary institutions operated in 26 units from 35 countries of the OECD. Independent budgetary institutions are available in all countries of the euro area (their mandatory existence is enshrined in the agreement on stability, coordination and management in the economic and monetary union), and in all countries of the European Union (except Poland) there is a need to monitor compliance with budgetary rules by organizations that are not dependent on financial institutions. It is indicated in the documents of the European Parliament and the Council of the EU. In general, independent budgetary institutions are available in a number of countries in 39 countries of the world, as well as in a number of emerging markets (for example, in recent years, independent budgetary institutions have been established in Iran, Kenya, Colombia, Peru, Uganda, South Africa) ${ }^{4}$.

There are associations of independent budgetary institutions in the OECD and the European Union, which annually hold a conference of its members (Since 2009 year in the OECD, EU from 2015 year). In 2014, the OECD Council approved the performance printouts of independent budgetary

\footnotetext{
${ }^{1}$ Elliott R. Morss Tax sharing: good and bad reasons for its adoption // National Tax Journal, Vol. 20, No.4 (December 1967), pp. 424-431. https://www.jstor.org/stable/41791569

${ }^{2}$ Our research shows that the practice of creating independent budgetary institutions does not always show the effectiveness of their activities. Along with positive experience, in a number of countries, long-standing discussions were noted with the problems of their interaction with government agencies, the official nature of the activity, the professionalism of specialists who are part of independent budgetary institutions.

${ }^{3}$ Adam Török and Anita Veres the role, operation and future of independent fiscal councils within the European Union// Acta Oeconomica, Vol. 61, No. 2 (June 2011), pp. 225-232. https://www.jstor.org/stable/41318104

${ }^{4}$ Beetsma, R., Debrun, X., Fang, X., Kim, Y., Lledo, V., Mbaye, S., \& Zhang, X. (2019). Independent fiscal councils: Recent trends and performance. European Journal of Political Economy, 57, 53-69.
} 
institutions, in 2016 the Association of independent budgetary institutions of the countries of the European Union approved the minimum standards of the activities of these institutions ${ }^{1}$.

As a result of the study, it was found that there are three institutional models of independent budgetary institution in world practice (See Fig. 2).

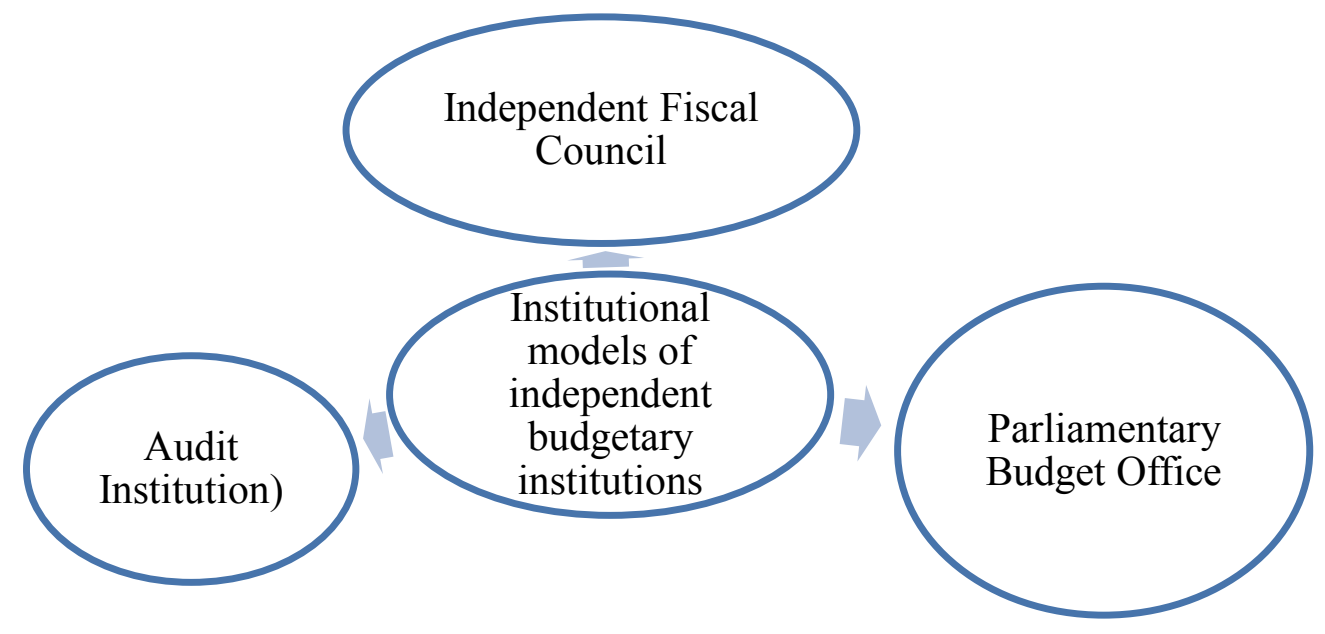

Fig.2. Institutional models of independent budgetary institutions

In 64 percent of most OECD countries, the Council of the Independent Budget Institute, the remaining 36 percent operate other models in the states. In particular, the parliamentary office for budget affairs 27 percent, the autonomous state audit body 9 percent ${ }^{2}$.

In general, when concluding, independent budgetary institutions dominate the byor of the Parliament on budgetary affairs in European countries, in other countries (USA, Australia, South Korea). The difference of these two main models is that the Independent Budget Institute is established under the government, the byuro parliament on Budgetary Affairs.

Uzbekistan is a new developing country, it is desirable to study in depth the experience of developed countries in the reform of public finance, improvement of the budget system and process, ensuring budgetary equivalency, as well as to proceed from the level of national development in the application in Uzbekistan.

Proceeding from this, we will analyze a comparative analysis of the experience of developed countries in the field of activity of independent budgetary institutions:

In the US, a five-year budget planning is used, but indicators are mandatory for the next financial year. The state budget project is prepared by the administration of the Presidential Administration and the budget department. The Budget Department of Congress will prepare a similar state budget project, but the ushbe budget project, which will be prepared by Congress, will be prepared for 10 years, and the projects for the next budget year will be presented separately.

In the US, the budget cycle will begin 18 months before the start of the next fiscal year (a leap year compared to other OECD countries). In April-May, The Management and Budget Department of the Presidential Administration sends an instructive letter to federal agencies. This letter sets out the general guidelines for the preparation of the budget for the upcoming budget period, as well as the preparation of preliminary data for the autumn analysis of budget proposals in cooperation with the departments. In July, the management and Budget Department №A11 will issue a circular. This circular will consist of detailed instructions for preparing and presenting the budget to all federal agencies for the fall analysis to The Management and Budget Department. From October to November, the Department of Management and Budget analyzes budget orders within the framework of the first-level tasks set by the President, evaluates the efficiency indicators of the programs and prepares the budget project. At the end of November, The Management and Budget department will provide budget information to the President and inform the

\footnotetext{
${ }^{1}$ Debrun, X., \& Takahashi, K. (2011). Independent Fiscal Councils in Continental Europe: Old Wine in New Bottles? CESifo DICE report, 9(3), 44-49.

${ }^{2}$ http://www.oecd.org/gov/budgeting/OECD-Independent-Fiscal-Institutions-Database.xlsx
} 
federal agencies of the projected budget assemblies. In December, agreements with agencies on the project will be implemented and the preparation of budget documents will be completed. On the first Monday of February, the President will present the budget draft to the parliament.

In the UK, budget assignations are accepted every year for one year, while budget projects are set for three years, but in two years they are considered a marotaba. In the budget documents, the maximum norms of expenditure for the main types of expenses for three years are indicated separately and the costs that are projected for three years, but which are fixed annually (social contributions, interest payments on debts, expenses that local government agencies make from the account of their own income) are indicated. Three-year cost standards are not of a legal nature, but are adhered to in the style of the rule.

The deadline for submission of the budget to the parliament is not determined by law in Great Britain. Proceeding from the General Chamber regulation, discussions on the assignations for the current year will be submitted on the expiration date -5 August. The Treasury sets up graphs and rules for the preparation and review of three-year budget projects of ministries. As a rule, firstly Cabinet confirms the main budget indicators, and then there will be an agreement on projects (in the summer and autumn of the year before the next budget year). The decision of the ministries on budgetary projects will be adopted by kabinet in November, until the preparation of the pre-budgetary report. In the spring, the Treasury Chancellor (Minister of Finance) in his statement on the budget will consider the issues of budgetary policy, bring the forecast for which macroeconomic indicators are determined and the original budget projects. Budget documents are approved by the Cabinet at the time when the chancellor made an exit in the budget parliament (in March-early April).

Traditional annual budget planning is used in Kazakhstan. The three-year budget, which began to be used from 2009 year, is drawn up according to the "Sliding three-year budgeting"1 method.

The budget draft tailoring cycle begins in February and ends until 1 August and is submitted to the government for consideration. A budget project is prepared on the basis of the following stages:

- preparation of the forecast of macroeconomic indicators for the next three-year period (up to 1 May);

- preparation of the "cost maximum"for the planning of budget expenditures for ministries by the Ministry of economy (until 7 May);

- preparation of budget orders of ministries (until 1 June);

- preparation of proposals on the volume of targeted transfers by ministries and the amount of budgetary credits from the budget of the Republic to the regional budgets (until 1 July);

- consideration of budget orders and proposals on the amount of budget transfers and credits by the Republican budget commission (until July 27); 1 August $)^{2}$

- preparation of the final version of the budget project and submission to the government (until

As we have already considered, considering the effectiveness and efficiency of state budget funds, we think that it is worthwhile to carry out work in the following directions in Uzbekistan on the basis of reforms in the budgetary sphere and their experience in the developed countries:

First of all, the introduction of a" sliding three-year" budget into budgetary practice in Uzbekistan.

In recent years, the state budget expenditures have been increasing as a result of institutional changes, due to the fact that the priority of people's interests, the appeal of citizens are not neglected by the state, which in turn negatively affects the stability of the state finances of the country. The practice of "sliding three-year budget", which implies the determination of the priority of costs, gives its positive result.

Second, to determine the cost maximums for ministries and departments in the formulation of the budget for the medium term;

Thirdly, it is important to pay attention to the fact that the cost maximums of budgetary organizations are based on indicators developed by ministries and departments.

\footnotetext{
${ }^{1}$ Act of the International Monetary Fund, 2007, on Code of good practices on fiscal transparency;

Financial Law Review. University of Gdansk. No. 2(4)/2017 quarterly. Faculty of law and administration http://www.ejournals.eu, http://czasopisma.bg.ug.edu.pl

${ }^{2}$ Beazley, I., Downes, R., \& Nicol, S. (2018). Budgeting in Kazakhstan A roadmap for continued for continued budgetary governance reform. OECD Journal on Budgeting, 18(3).
} 